\author{
FABRIZIO PENNACCHIO $(*)$ - LEONARDO MARIANELLI $(*)$ - FRANCESCO BINAZZI $(*)$ \\ VALERIA FRANCARDI $(*)$ - FRANCESCO PAOLI $(*)$ - RAFFAELE GRIFFO $(* *)$ - PIO FEDERICO ROVERSI $(*)$
}

\title{
FIRST INTERCEPTION OF TRICHOFERUS CAMPESTRIS (FALDERMANN, 1835) (COLEOPTERA CERAMBYCIDAE CERAMBYCINAE) IN ITALY
}

\author{
(*) Consiglio per la ricerca in agricoltura e l'analisi dell'economia agraria - Research Centre for Agrobiology and \\ Pedology, via Lanciola 12/a, 50125, Firenze, Italy; E-mail: fabrizio.pennacchio@crea.gov.it \\ (**) Servizio Fitosanitario Regione Campania. Centro Direzionale - Isola A6 - 80146, Napoli.
}

\begin{abstract}
Pennacchio F., Marianelli L., Binazzi F., Francardi V., Paoli F., Griffo R., Roversi P.F. - First interception of Trichoferus campestris (Faldermann, 1835) (Coleoptera Cerambycidae Cerambycinae) in Italy.

The Velvet Longhorned Beetle Trichoferus campestris (Faldermann, 1835) was intercepted for the first time in Italy, in the Naples harbour, during monitoring activities at entry points carried out in the context of the national project ASPROPI. T. campestris is widely polyphagous and able to colonize several woody species in both agricultural and forest environments. Moreover timber and solid wood items can be equally attractive to this pest. This additional report, in an area where other alien insect species had been identified in the past, emphasises how the national monitoring network represents a key element of the alert system designed to quickly counter the accidental introduction and spreading of exotic insect pests.
\end{abstract}

KEY WorDS: Velvet Longhorned Beetle, exotic species, Southern Italy.

\section{INTRODUCTION}

Wood is widely used in trades either as a commodity itself or as packaging material for several products. Regrettably, in the absence of phytosanitary measures, it may represent an efficient vector of many xylophagous insects, increasing the risk of pest introductions in new areas (CAVEY, 1998; HAACK, 2001, 2006; HAACK et al., 2010; LiebHold et al., 1995 McCullough et al., 2006; Aukema et al., 2010; HAACK and RABAglia, 2013; PenNACCHIO et al., 2003, 2004, 2013). In recent decades, during monitoring activities, hundreds of xylophagous species, belonging mainly to the families Cerambycidae, Buprestidae, Bostrichidae and Curculionidae (particularly Scolytinae) have been intercepted worldwide in high-risk areas such as ports, airports, customs and nurseries. Since then, a vast number of introduced species have become naturalized showing a strong capacity to spread to new territories, quickly adapting to different ecological conditions. This often led to negative consequences in terms of ecosystem efficiency and host plant health (INGHILESI et al., 2013; Pennacchio et al., 2013; Herard et al., 2009; BULLAS-APPLETON et al., 2014). In this regard, for example, negative outcomes due to the introduction of Anoplophora chinensis (Forster, 1771), A. glabripennis (Motschulsky, 1853) (Coleoptera Cerambycidae) and Xylosandrus compactus (Eichhoff, 1875) (Coleoptera Curculionidae Scolytinae), responsible for severe damages to broadleaved trees in urban and suburban areas, have been often observed. Moreover Megaplatypus mutatus (Chapuis, 1865 ) and Aclees sp. cf. foveatus Voss (Coleoptera Curculionidae) have been also reported to be harmful to poplar plantations and fig trees, respectively (TREMBLAY et al., 2000; CIAMPOLINI et al., 2005; MASPERO et al., 2007; Allegro and Griffo, 2008; Herard et al., 2009; PENNACCHIO et al., 2012).
Thanks to the monitoring activities carried out in the project ASPROPI, a specimen of Trichoferus campestris (Faldermann, 1835) (Coleoptera Cerambycidae) (Velvet longhorned beetle) was captured by funnel traps located in the port of Naples, Southern Italy: the identification of the specimen was made using the keys of HegYessy and KUTASI (2010).

\section{DISTRIBUTION}

The genus Trichoferus Wollaston, 1854, belongs to the family Cerambycidae and includes 7 species in continental Europe: T. fasciculatus (Faldermann, 1837), T. griseus (Fabricius, 1792)(Fig. I, 2), T. holosericeus (Rossi, 1790) (Fig. I, 3), T. magnanii Sama, 1992, T. pallidus (Olivier, 1790)(Fig. I, 1), T. spartii (G. Müller, 1948) and T. campestris. In Italy only $T$. fasciculatus, $T$. griseus, $T$. spartii, T. pallidus, T. arenbergeri Holzschuh, 1995, endemic of Sardinia and T. holosericeus have been recorded (SAMA and RAPUZZI, 2011; RAPUZZI and GREGO, 2013).

T. campestris is native to China, Japan, Korea, Mongolia, India, Kyrgyzstan, Tajikistan, Turkmenistan and Uzbekistan, the easternmost part of Russia, European and south eastern Russia and the southern Urals (KRIVOSHEINA and Tokgaev, 1985; EPPO, 2009; GreBenNiKov et al., 2010).

Either stabilized populations or simple interceptions of this species have been recorded in many areas outside its native range such as central and southern Russia, Ukraine, Georgia, Iran, Iraq, Poland, Moldavia, Romania, Moravia (Czech Republic), Slovakia, Hungary, Romania, France, the eastern Mediterranean area, North America, Indian Ocean and Pacific Ocean (DANILEVSKY and Miroshnikov, 1985; MAKHNOVSKII, 1966; DASCĂLU et al., 2013; COCQUEMPOT, 2006; SABOL, 2009; SAMA et al., 2005; KRUSZELNICKI, 2010; HegYessy and Kutasi, 2010; ZAMOROKA and PANIN, 2011; Bullas-Appleton et al., 2014; WATSON et al., 2015; THE 


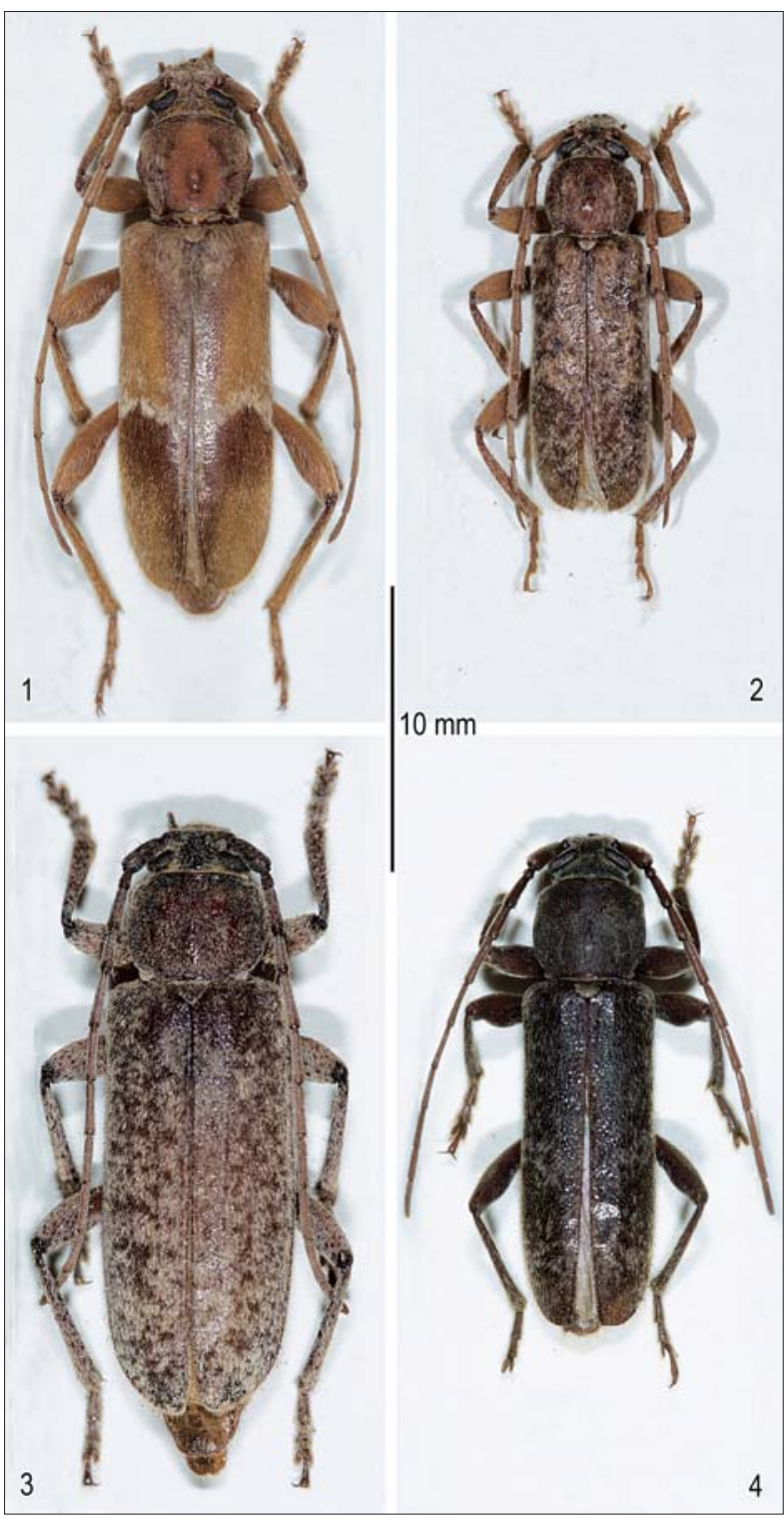

Fig. I-1. Trichoferus pallidus ; 2. T. griseus ; 3. T. holosericeus; 4. T. campestris.

Food \& Environment Research Agency, 2014). This species has been also intercepted in Israel, Jordan, Lebanon, Syria, northeast Africa (Egypt, Sinai Peninsula), Sweden, Turkey and France (CocQuempot, 2006; SABol, 2009; BOZKURT et al., 2013; DASCǍLU et al., 2013; THE FOOD \& ENVIRONMENT RESEARCH AgENCY, 2014).

\section{BIOLOGY}

T. campestris (Fig. I, 4) develops in woody plants in both agricultural and forest environments. It is active during the night, flying regularly from the end of June to the beginning of August when females lay eggs into the bark of tree trunks and large-diameter branches. Healthy or stressed plants are usually colonized but any wood material, though very dehydrated, can be equally attractive. In laboratory conditions, T. campestris is able to colonize plants and to develop even in small-diameter branches from 2.5 to 3.0 $\mathrm{cm}$. Young larvae initially form galleries between the tree bark and the cambium and then penetrate into the xylem. In fact, bark was often reported to play a key role in $T$. campestris oviposition and subsequent development of its larvae, particularly in the first phase of their life (IVATA and YAMADA, 1990). On the other hand, older larvae usually feed on the external xylem showing a strong capacity to adapt to their substrate even when it is strongly dehydrated. This species usually overwinters in the larval stage under the bark or in pupal chambers and its galleries can be up to $12 \mathrm{~mm}$ broad. Some authors argued that its life cycle is completed in two years (PLAVILSHCHIKOV, 1940; PAVLOVSKII and Stackelberg, 1955; Makhnovskiy, 1966; Kostin, 1973) while others stressed the importance to complete the cycle in a period longer than two years (CHEREPANOV, 1981; DANILEVSKII and MiroshNIKOV, 1985; LER, 1996).

\section{HOST PLANTS}

T. campestris is widely polyphagous and able to colonize several woody species representing essential components of forests, orchards, and street tree populations in Italy and more generally in the EPPO countries. It has been observed to colonize healthy plants belonging to several species included in the genera: Picea, Pinus, Betula, Broussonetia, Gleditsia, Malus, Morus, Salix, Sorbus; when the wood is dehydrated, it is able to exploit an increased number of plant genera and species including: Abies spp., Larix spp., Picea spp., several Pinus such as Pinus densiflora and also Chamaecyparis obtusa, Betula, Fagus crenata, Juglans mandshurica, Morus bombycis, Robinia pseudoacacia, Zelkova serrata, Vitis vinifera, Acer spp., Alnus spp., Aralia spp., Camellia japonica, Carpinus, Citrus, Cornus, Diospyros, Euonymus, Fraxinus, Ilex, Malus, Populus, Pyrus, Rhus, Salix, Syzygium, Tilia, Ulmus, Wisteria, Quercus, Zanthoxylum, Ziziphus (ORLINSKI, 2006; EWBBB, 2014).

\section{PHYTOSANITARY RISK}

In 2007, T. campestris was included in the EPPO A2 action list and it is currently considered a quarantine insect not only in the USA and Canada but also in the EPPO countries where there is a risk of introduction. In fact, together with its congeneric species reported in the European fauna, it is often responsible for damages to live trees, dehydrated wood, and, in some circumstances, solid wood items. Therefore, since this species has the potential to establish permanently in the vast majority of regions of central and southern Europe, including Italy, it is regarded as a possible threat to biodiversity (MAKHNOVSKII, 1966; Kostin, 1973; KrIVOSHeINA and TOKGAEV, 1985).

Phytosanitary MEASURES AIMED AT LIMITING PEST SPREADING

The main vector, responsible for the artificial introduction of $T$. campestris in new geographic areas, is certainly infested wood and in particular packaging material that may host larvae, pupae and adults.

In 2002, specimens of $T$. campestris emerged in a quarantine area of the Marseille harbour (France) from Salix sp. timber shipped from China (COCQUEMPOT, 2006). In 2015, in Austria, T. campestris specimens were intercepted 3 times on packaging material from China marked with the ISPM-31 (EUROPHYT, 2016). Thanks to these last interceptions, made also with the help of dogs, live larvae, pupae and adults of this species could be detected.

Since this pest is able to develop even in highly dehydrated wood, trade of packaging material represents indeed the main spreading route. So far, phytosanitary measures adopted to limit pest introductions included the 
early debarking of logs and accurate wood inspections aimed at detecting characteristics diagnostic of xylophagous insects (i.e. frass and gallery systems).

However, we stress that the compliance with the current international legislation concerning phytosanitary measures for packaging material, in agreement with the FAO requirements (ISPM No. 15) (2013), is essential in the implementation of strategies aimed at preventing unintentional pest transfer.

This specimen was collected thanks to a national monitoring network established in the Naples harbour by MIPAAF in cooperation with the regional phytosanitary services, CREA and other scientific institutions. In the same area, an outbreak of Aromia bungii (Faldermann, 1835) (Coleoptera Cerambycidae) had been detected in 2012 (EPPO, 2012; EPPO, 2015).

Such results underline that the active monitoring of areas at risk of pest introduction, represents a key element of the alert system designed to quickly counter the accidental introduction and spreading of exotic insects in the Italian territory.

\section{ACKNOWLEDGMENTS}

This work was carried out in the context of the National Project "ASPROPRI - Activities for the protection of plants", funded by MIPAAF (Italian Ministry of Agricultural Food and Forestry Policies, DM n. 28635, 2015/12/28,)

We wish to thank the phytosanitary inspector Dr. Elio Minucci (Port of Naples), who has been actively involved in monitoring.

\section{REFERENCES}

Allegro G., Griffo R., 2008 - I rischi di diffusione di Megaplatypus mutatus. - Informatore Agrario, 64 (13): 73-76.

Aukema J.E., McCullough D.G., Von Holle B., Liebhold A.M., Britton K., Frankel, S.J., 2010 Historical accumulation of nonindigenous forest pests in the continental US. - BioScience, 60, 886-897.

BozKurT V., ÖZdEM A., AYAN E., 2013 - Coleopteran pests intercepted on imported forest products in Turkey. Book of proceedings of IV International Symposium "Agrosym 2013”. Jahorina, October 3 - 6, 2013: 646-652.

Bullas-Appleton E., Kimoto T., Turgeon J.J., 2014 Discovery of Trichoferus campestris (Coleoptera: Cerambycidae) in Ontario, Canada and first host record in North America. - Can. Entomol. 146: 111-116.

CAVEY, J.F., 1998 - Solid wood packing material from China, initial pest risk assessment on certain wood boring beetles known to be associated with cargo shipments: Asian Longhorned Beetle (Anoplophora glabripennis), Ceresium, Monochamus and Hesperophanes. USDA PPQ, 22pp.

CherePANOv A.I., 1981 - Longhorn Beetles of Northern Asia (Cerambycidae). Nauka Press, Novosibirsk, Russia. 216 pp (in Russian). English translation: Cerambycidae of Northern Asia. Volume 2, Part 1 Cerambycinae. E.J. Brill, Leiden, The Netherlands. 292 pp.

Ciampolini M., Perrin H., Regalin R., 2005 - Aclees cribratus, nuovo per l'italia nocivo al fico allevato in vivaio. - Informatore Agrario, 61: 69-71.

Cocquempot, C., 2006 - Alien longhorned beetles (Coleoptera Cerambycidae): Original interceptions and introductions in Europe, mainly in France, and notes about recently imported species. - Redia, 89: 35-50.

Danilevsky, M.L., MiroshniKov A.I., 1985 - Longhorn beetles of Caucasus (Coleoptera, Cerammbycidae). Taxonomic Keys. - Nauka Press, Krasnodar, Russia. 419 pp (in Russian).

DASCĂLu, M.M., SERAFIM, R., Lindelow, A., 2013 - Range expansion of Trichoferus campestris (Faldermann) (Coleoptera: Cerambycidae) in Europe with the confirmation of its presence in Romania. - Entomologica Fennica, 24: 142-146.

EPPO, 2009 - Hesperophanes campestris. - Bulletin OEPP/EPPO 39: 51-54.

EPPO 2012 - First report of Aromia bungii in Italy. - EPPO Reporting Service, 2012-10-01, 2012/204.

EPPO, 2015 - Aromia bungii. EPPO Bull, 45: 4-8. doi:10.1111/epp.12173

EUROPHYT, 2016 - data processed - https://webgate.ec. europa.eu/europhyt.

EWBBB_2014, Exotic Wood Borer/Bark Beetle Trichoferus campestris (Faldermann), datasheet http://www.google.it/url?sa=t\&rct=j\&q=\&esrc=s\&source $=$ web\&cd $=5 \&$ cad $=$ rja\&uact $=8 \&$ ved $=0$ ahUKEwjBp7f9 NPLAhXKDywKHRQeDeQQFghCMAQ\&url=http\%3A $\% 2 \mathrm{~F} \% 2 \mathrm{Fdownload}$.ceris.purdue.edu $\% 2 \mathrm{Ffile} \% 2 \mathrm{~F} 2204 \& \mathrm{u}$ sg=AFQjCNGovtT5xpn_m_oMMH8VAxUboPDzQ\&si $\mathrm{g} 2=\mathrm{nxD} 8$ AV9E5Pk40JCgUqYu5w\&bvm=bv.117218890, d.bGg. (last date access, $22^{\text {th }}$ march 2016)

FAO, 2013 - ISPM 15, Guidelines for regulating wood packaging material in international trade. https://www.ippc.int/static/media/files/publication/en/201 6/01/ISPM_15_2013_En_2015-12-22_PostCPM10 InkAmReformatted.pdf.

Grebennikov, V.V., Gill B.D., Vigneault R., 2010 Trichoferus campestris (Falmermann) (Coleoptera: Cerambycidae), an Asian wood-boring beetle recorded in North America. - The Coleopterists Bulletin 64: 13-20.

HAACK R.A., 2001 - Intercepted Scolytidae (Coleoptera) at U.S. ports of entry: 1985-2000. - Integrated Pest Management Reviews, 6: 253-282.

HAACK R.A., 2006 - Exotic bark- and wood-boring Coleoptera in the United States: recent establishments and interceptions. - Can. J. For. Res., 36: 269-288.

HAACK R.A., HÉrard F., Sun J., Turgeon J.J., 2010 Managing invasive population of Asian Longhorned Beetle and Citrus Longhorned Beetle: a worldwide perspective. - Ann. Rev. Ent., 55: 521-546.

HaACK R.A., Rabaglia R.J., 2013 - Exotic bark and ambrosia beetles (Coleoptera: Curculionidae: Scolytinae) in the United States: potential and current invaders. In: Peña JE (ed) Potential invasive pests of agricultural crops. CAB International, Wallingford, UK, pp. 48-74.

HegYeSSY G., KutASI C.S., 2010 - Trichoferus species new to Hungary (Coleoptera: Cerambycidae). - Folia Entomologica Hungarica, 71: 35-41.

Herard F., Maspero M., Ramualde N., Jucker C., Colombo M., Ciampitti M., Cavagna B., 2009 Anoplophora glabripennis infestation (Col.: Cerambycidae) in Italy. - Bulletin OEPP/EPPO Bulletin 39: 146-152.

Inghilesi A.F., Mazza G., Cervo R., Gherardi F., Sposimo P., Tricarico E., Zapparoli M., 2013 - Alien insects in Italy: Comparing patterns from the regional to European level. - Journal of Insect Science, 13:73, 13 pp., http://www.insectscience.org/13.73.

Ivata R., Yamada F., 1990 - Notes on the biology of Hesperophanes campestris (Faldermann) (Col., 
Cerambycidae), a drywood borer in Japan. - Material und Organismen, 25(4): 305-313.

Kostin I.A., 1973 - [Dendrophagous Beetles of Kazakhstan (Buprestidae, Cerambycidae, Ipidae)]. Izdadel'stvo Instituta Zoologii Academii Nauk Kazakhskoi SSR, Alma-Ata, 278 p. (in Russian).

KRIVOSHEINA N.P., TOKGAEV T.V., 1985 - [The formation of trunk insect complexes on irrigated lands in the KopetDag foothills]. Izvestiya Academii Nauk Turkmenskoi SSR (5), 34-39, Biologicheskie Nauki, No. 5 (in Russian).

KRUSZELNiCKI L., 2010 - Trichoferus campestris (Faldermann, 1835) (Coleoptera: Cerambycidae) in Poland. Acta entomologica silesiana, 18: 33-34 (in Polish).

LER P.A. (Ed.), 1996 - [Taxonomic Keys for Insects of Russian Far East. v. III, part 3, Coleopterous, or Beetles]. Dal'nauka, Vladivostok, 556 p. (in Russian).

LiebHold A.M., MAcdonald W.L., Bergdahl D., Mastro V.C., 1995 - Invasion by Exotic Forest Pests: A Threat to Forest Ecosystems. - Forest Science Monographs 30, 49 pp.

MAKHNOVSKII I.K., 1966 - [Mulberry longhorn beetle Trichoferus campestris Fald]. In: Vrediteli Gornykh Lesov I Bor'ba S Nimi, pp. 88-89. Lesnaya Promyshlennost', Moscow, (in Russian).

Maspero, M., Cavalieri, G., D'Angelo, G., Jucker, C., Valentini, M., Colombo M., Herard F., Lopez J., Ramualde N., Ciampitti M., Caremi G., Cavagna B., 2007 - Anoplophora chinensis - eradication program in Lombardia (Italy). https://www.eppo.int/QUARANTINE/ special topics/anoplophora chinensis/chinensis IT 2007 .htm

McCullough D.G., Work T.T., Cavey J.F., Liebhold A.M., Marshall D., 2006 - Interceptions of nonindigenous plant pests at US ports of entry and border cros - sings over a 17-year period. - Biol. Invasions, 8: 611-630.

ORLINSKI, A. D., 2006 - Outcomes of the EPPO project on quarantine pests for forestry. - EPPO Bulletin, 36: $497-$ 511.

PaVlovskit E.N., Shtakelberg A.A. (Ed.), 1955 - [Forest pests. Guide]. Izdatel'stvo Zoologicheskogo Instituta Akademii Nauk SSSR, Moscow - Leningrad, 1, 421 pp. (in Russian).

Pennacchio F., Roversi P.F., Francardi V., Gatti E., 2003 - Xylosandrus crassiusculus (Motschulsky) a bark beetle new to Europe. - Redia, 86: 77-80.

Pennacchio F., Faggi M., Gatti E., Caronni F., Colombo M., Roversi P.F., 2004 - First record of Phloeotribus liminaris (Harris) in Europe (Coleoptera Scolytidae). Redia, 87: 85-89.

Pennacchio F. Santini L., Francardi V., 2012 Bioecological notes on Xylosandrus compactus (Eichhoff) (Coleoptera Curculionidae Scolytinae), a species recently recorded into Italy. - Redia, 95: 67-77.

Pennacchio F., Danti R., Benassai D., Squarcini M., Marziali L., Di Lonardo V., Roversi P.F., 2013 - A new additional record of Phloeosinus armatus Reitter from Italy (Coleoptera Curculionidae Scolytinae). - Redia, 96: 45-50.

PlaVilshChIKOV N.N., 1940 - [Trichoferus campestris (Fald.)]. In: Fauna SSSR, Coleopterous insects, V. XXII; Longhorn beetles, Part 2, pp. 69-71. Izdatel'stvo Akademii Nauk SSSR, Moskva-Leningrad (RU) (in Russian).

RAPUZZI P. and GREgo B., 2013. First record of Trichoferus pallidus (Olivier, 1790) for Italy (Coleoptera: Cerambycidae). Munis Entomology \& Zoology, 8 (2): 712-713.

SABOL, O., 2009 - Trichoferus campestris (Coleoptera: Cerambycidae) - a new species of longhorn beetle for the Czech Republic and Slovakia. - Klapalekiana, 45: 199201.

Sama, G., Fallandhzadeh M., Rapuzzi P., 2005 - Notes on some Cerambycidae (Coleoptera) from Iran with description of two new species (Insecta Coleoptera Cerambycidae). - Quaderno di Studi e Notizie di Storia Naturale della Romagna, 20: 123-132.

SAma G., RApuzzi P., 2011 - Una nuova Checklist dei Cerambycidae d'Italia. - Quad. Studi Nat. Romagna, 32: 121-164.

The Food \& Environment Research Agency; 2014 Rapid Pest Risk Analysis for Trichoferus campestris. 7 pp. https://secure.fera.defra.gov.uk/phiw/riskRegister/planthealth/documents/ trichoferusCampestris.pdf

Tremblay, E., Espinosa B., MANZINI D., CAPrio G.. 2000 Un coleottero proveniente dal Sudamérica minaccia $i$ pioppi. - L'Informatore Agrario 48: 89-90.

WATSON K., PRATT C.A., CAPUTO J., 2015 - Total Records of Velvet Longhorn Beetle Trichoferus campestris Faldermann (Coleoptera, Cerambycidae) from Utah. http://ag.utah.gov/ documents/Insect Velvet Longhorn Beetle.pdf.

ZAMOROKA, A. M., PANIN, R. Y., 2011 - Recent records of rare and new for Ukrainian Carpathians species of Longhorn beetles (Insecta: Coleoptera: Cerambycidae) with notes on their distribution. - Munis Entomology \& Zoology, 6 (1): 155-165. 